\title{
Dampak Pembelajaran Daring Selama Pandemic Terhadap Kemampuan Kognitif Peserta Didik
}

\author{
1Dewi Niswatul Fithriyah, ${ }^{2}$ Suttrisno ${ }^{3}$ Nurul Mahruzah Yulia, ${ }^{4}$ Fiki Dzakiyyatul Aula \\ 123Universitas Nahdlatul Ulama Sunan Giri Bojonegoro , 2STIT Muhammadiyah Bojonegoro \\ E-mail: 1ㄹewiniswatul@unugiri.ac.id, ${ }^{2}$ suttrisno@unugiri.ac.id ${ }^{3}$ nurulmahruzah@unugiri.ac.id, \\ 4fikyaula@gmail.com
}

\begin{abstract}
Abstrak
Akhir-akhir ini kita dihadapkan pada situasi yang belum pernah kita alami. Negara kita telah digembarkan oleh sebuah virus Corona (covid-19) yang sangat berbahaya bagi manusia. Covid-19 merupakan sebuah virus yang bisa menular dari satu individu ke individu yang lain dengan waktu yang relative singkat. Sehingga untuk meminimalisir penyebaran covid-19 tersebut diberlakukan berbagai kebijakan. Adanya covid-19 yang tak kunjung usai ini sangat berdampak pada semua aspek, seperti aspek ekonomi, sosial, budaya dan tak terkecuali aspek Pendidikan. Dalam pelaksanaan Pendidikan, semua jenjang pendidik yang awalnya dilakukan dengan melakukan pembelajaran tatap muka kini harus dilakukan dengan cara berbeda, yaitu dengan daring/online. Penulisan artikel ini bertujuan untuk memaparkan bagaiman dampak pembelajaran daring terhadap kemapuan kognitif anak selama pandemic covid-19. Kajian ini dilakukan dengan studi Pustaka dari berbagai jurnal, dan karya tulis ilmiah serta observasi dilapangan selama pandemic. Selain itu juga dilakukan dengan partisipasi secara langsung selama proses pembelajaran daring. Kesimpulan dari artikel ini bahwa pembelajaran yang dilakukan secara daring selama pandemic ini memiliki dampak positif dan juga dampak negative terhadap kemapuan kognitif peserta didik.
\end{abstract}

Kata kunci: Pembelajaran daring/online, covid-19, perkembangan kognitif

\begin{abstract}
Lately, we faced with situations that we have never experienced before. Our country has been attacked by a very dangerous virus for humans, the virus called Covid-19. Covid-19 is a virus that can be transmitted from one individual to another in a relatively short time. In order to minimize the spread of COVID-19, various policies have been put in place. The existence of Covid-19, which never end, had impacts on all aspects, such as economic, social, cultural aspects, and education is no exception. In the implementation of education, all levels of educators which were initially carried out by conducting face-to-face learning must now be carried out in a different way, namely online learning. The aims of writing this article is to explain how the impact of online learning on children's cognitive abilities during the covid-19 pandemic. This study was conducted using literature studies from various journals, and scientific writings and field observations during the pandemic. In addition, it is also done by direct participation during the online learning process. The conclusion from this article is that online learning during this pandemic has both positive and negative impacts on students' cognitive abilities.
\end{abstract}

Keywords: online learning, covid-19, cognitive development 


\section{PENDAHULUAN}

Paradigma untuk mengukur suatu kemajuan bangsa ini telah bergeser dari yang awalnya bertumpu pada kekayaan sumber daya alam menjadi bertumpu pada sumber daya manusia (nata, 2009). Untuk menciptakan sumber daya manusia yang unggul bisa dilakukan melalui pendidikan. Pendidikan merupakan suatu hal yang sangat penting dan sangat dibutuhkan untuk menciptakan generasi bangsa yang berkualitas dan berdaya saing. Pendidikan harus dijalankan dengan konsep dan arah yang jelas serta sempurna agar hasil outputnya sesuai dengan apa yang diharapkan.

Akan tetapi selama dua tahun terahir ini, dunia pendidikan mengalami goncangan yang luar biasa. Goncangan tersebut disebabkan oleh adanya sebuah virus yang sangat tidak terduga kehadirannya. Virus itu disebut dengan Corona Virus Desease (Covid-19). Covid-19 ini awal mulanya muncul di daerah Wuhan yang ada di negara China. Akan tetapi seiring berjalannya waktu, Covid-19 ini menyebar dengan sangat pesat bahkan sampai ke negara Indonesia. Akibat adanya virus ini tidak sedikit masyarakat Indonesia yang terinfeksi dan akhirnya meninggal dunia.

Berbagai upaya telah dilakukan oleh pemerintah Indonesia untuk mencegah penularan dan juga penyebaran Virus Corona. Salah satu upaya yang dilakukan adalah dengan menerapkan social distancing dan juga physycal distancing (Kusuma \& Sutapa, 2021). Dampak dari kebijakan ini sangat bisa dirasakan oleh masyarakat Indonesia terutama dalam bidang sosial, ekonomi, pariwisata dan yang lebih penting adalah dalam dunia pendidikan (Dewi, 2020).

Akibat adanya Covid-19 yang tak kunjung usai, pada tanggal 18 Maret 2020 pemerintah mengeluarkan Surat Edaran (SE) bahwa segala jenis yang terjadi di luar ataupun di dalam ruangan sementara waktu di tunda untuk meminimalisir penyebaran covid-19 terutama dalam bidang pendidikan (Dewi, 2020). Akibatnya, pendidikan di Indonesia harus mengalami perombakan dalam pelaksanaannya. Pendidikan yang dituangkan dalam kegiatan pembelajaran mengalami perubahan dalam proses pelaksanaannya. Pembelajaran yang awalnya bisa dilakukan dengan tatap muka kini harus dilakukan dengan cara daring/online. Pembelajaran daring merupakan suatu bentuk pembelajaran yang dilakukan dengan memanfaatkan kecanggihan teknologi seperti komputer, handphone, dan juga gadget yang terkoneksi dengan internet (Kuntarto, 2017). Selama pembelajaran daring, waktu belajar sangat fleksibel karena belajar dapat dilakukan dimanapun dan kapanpun. Kecanggihan teknologi sat ini juga sangat memudahkan peserta didik untuk tetap beriteraksi dengan pendidik melalui aplikasi classroom, video conference, zoom, Ms Team, live chat, dan juga Whatsapp group.

Hal ini sangat berdampak besar terhadap proses pembelajaran hususnya di tingkat sekolah dasar yang memang semestinya belum cukup usia sebagai user smartphone juga tidak semua peserta didik memilikinya (hasil observasi). Pembelajaran selama daring dilakukan dengan sangat terbatas melalui whatsapp group. Aplikasi whatsapp group tersebut menjadi sebuah sarana untuk memberikan materi pembelajaran yang biasanya disajikan dengan memberikan video yang diunduh dari youtube, pemberian penjelasan yang teramat singkat, dan juga untuk memberikan tugas kepada peserta didik. Oleh karena itu pembelajaran yang seperti ini sangat berdampak terhadap perkembangan aspek kognitif peserta didik.

Berdasarkan uraian diatas, maka peneliti mengangkat sebuah tema Dampak pembelajaran DARING selama pandemic terhadap kemampuan kognitif peserta didik. Adapun tujuan dari penelitian ini adalah untuk mengetahui apa dampak yang ditimbulkan dengan diterapkannya pembelajaran daring terhadap kemampuan kognitif 
peserta didik yang ada di salah satu madrasah ibtidaiyah di kecamatan Montong kabupaten Tuban.

\section{METODE PENELITIAN}

Penelitian ini menggunakan metode kualitatif. Menurut Moleong, penelitian kualitatif adalah penelitian yang bermaksud untuk memahami fenomena tentang apa yang dialami oleh subjek penelitian misalnya perilaku, presepsi, motivasi tindakan dan lain-lain secara holistic, dan dengan cara deskripsi dalam bentuk kata-kata dan bahasa, pada suatu konteks khusus yang alamiah dan dengan memanfaatkan berbagai metode alamiah (Moleong, 2005). Penelitian ini dilakukan penulis di MI Islamiyah Pakel Kecamatan Montong Kabupaten Tuban pada tahun ajaran 2020-2021 selama masa pandemic.

Adapun teknik yang dilakukan oleh penulis dalam pengumpulan data adalah dengan teknik observasi di lapangan selama pandemic dan juga studi Pustaka dari berbagai jurnal dan karya tulis ilmiah yang relevan. Teknik observasi adalah ketika peneliti langsung turun ke lapangan untuk mengamati prilaku dan aktifitas perilaku dan aktifitas individu-individi di likasi peneitian (Cresswell, 2017). Dalam teknik observasi peneliti meneliti, merekam/mencatat baik secara terstruktor maupun semistruktur aktifitas-aktifitas di lokasi penelitian, dan kemudian peneliti membuat laporan berdasarkan apa yang dilihat, didengar dan dirasakan selama observasi.

\section{HASIL DAN PEMBAHASAN}

Selama dua tahun terahir ini, seluruh dunia dikagetkan dengan adanya virus yang tidak terduga. Virus tersebut disebut dengan Corona Virus Desease (Covid-19). Munculnya covid ini mampu memberikan efek dan dampak yang luar biasa terhadap berbagai negara. Salah satunya adalah negara Indonesia. Di Indonesia, Covid mampu memberikan efek dan dampak yang luar biasa dalam berbagai aspek. Entah itu dalam aspek ekonomi, aspek budaya, dan juga dalam aspek pendidikan.

Covid-19 ini dirasa sangat berdampak besar terhadap generasi penerus bangsa yaitu para pemuda-dan juga pemudi yang masih harus mempersiapkan dirinya melalui proses pendidikan di sekolah. Dalam dunia pendidikan dampak adanya covid ini sangatlah dirasa. Akibat pandemic covid-19 yang tak kunjung usai ini imbasnya adalah adanya berbagai peraturan-peraturan baru yang memiliki sisi negatif dan positif dalam dunia kependidikan.

Salah satu upaya yang dilakukan oleh pemerintah adalah dengan memberikan peraturan yangs sesuia dengan surat edaran dari Kemendikbud RI Nomor 4 Tahun 2020 tentang pelaksanaan kebijakan pendidikan dalam masa darurat penyebaran virus corona virus desease (Covid-19) serta mengikuti dan mentaati edaran dan juga himbauan dari daerah masing-masing. Berdasarkan himbauan dari pemerintah, bahwa segala proses pembelajaran baik disekolah ataupun di perguruan tinggi harus dilakukan secara daring (dalam jaringan). Kebijakan tersebut merupakan salah satu upaya yang dilakukan untuk menekan penyebaran virus covid agar tidak semakin merajalela (hidayati \& aslam, 2021). Akan tetapi, pembelajaran secara daring ini memiliki dampak yang positif dan juga negatif terhadap proses pembelajaran.

Pandemic yang tak kunjung usai ini merubah proses pembelajaran yang semula bisa dilakukan secara tatap muka kini harus dilakukan dengan jarak jauh atau daring (chusna \& utami, 2020). Pembelajaran daring ini dilakukan sesuai dengan kondisi atau kemampuan dari masing-masing sekolah. Untuk memperlancar proses pembelajaran daring ini terdapat banyak aplikasi digital yang bisa dimanfaatkan. Aplikasi tersebut adalah classroom, video conference, zoom, Ms Team, live chat, dan juga Whatsapp group. Dalam praktiknya pembelajaran daring ini melibatkan banyak orang. Pendidik harus 
berkolaborasi dengan orang tua untuk bisa memaksimalkan anak dalam belajar (kahfi, 2021).

Selama pembelajaramn daring ini media yang paling mungkin untuk digunakan adalah handphone. Melalui berbagai aplikasi belajar yang bisa diinstal melalui handphone akan memunculkan berbagai pengalaman baru dalam belajar. Selain itu, pendidik juga mendapatkan pelajaran baru terkait perihal pengelolaan kelas, penggunaan strategi pembelajaran, modul, dialog, serta konten. Melalui media digital ini, peserta didik akan memiliki banyak kesempatan untuk memperluas pemahaman terhadap berbagai materi dengan memanfaatkan teknologi informasi yang begitu canggih dan bisa diakses dimanapun dan kapanpun. Akan tetapi dalam mengefektifkan pembelajaran daring ini haruslah dilakukan dengan melakukan perencanaan yang matang, strategi pembelajaran serta strategi penyampaian yang baik, pengelolaan kelas yang sesuai, serta penilaian atau evaluasi yang sesuai.

Model pembelajaran daring ini memiliki sisi positif dan juga sisi negatif. Sisi positif dari pembelajaran daring ini adalah peserta didik dapat belajar tanpa terbatas waktu. Peserta didik bisa belajar kapanpun, dimanapan, dan dengan siapapun. Proses pembelajaran yang fleksibel ini sangat nyaman untuk dilakukan. Karena jika peserta didik sudah mulai lelah dalam belajar, ia bisa berhenti sejenak dan melanjutkannya kembali. Selain itu peserta didik juga memiliki kemudahan untuk mengakses berbagai materi pelajaran untuk memperluas knowledge-nya dengan memanfaatkan media digital. Orang tua peserta didik juga memiliki banyak kesempatan untuk memantau anak dalam proses pembelajaran sehingga terjalin kolaborasi positif antara peserta didik dan orang tua.

Akan tetapi, selain sisi positif yang ditimbulkan, pembelajaran juga memiliki sisi negatif. Sisi negatif dari pembelajaran daring ini adalah mengharuskan siswa untuk memiliki sarana dan prasarana yang mendukung. Minimal peserta didik harus memiliki handphone dengan kualitas yang bagus dan mendukung adanya aplikasi-aplikasi pembelajaran. Bukan hanya itu, selain harus memiliki sarana yang canggih, Handphone yang digunakan haruslah terhubung dengan internet, sehingga peserta didik harus menyisihkan sedikit dana untuk bisa menyambung ke internet dengan cara mengisi paket datanya. Kedua syarat tersebut haruslah terpenuhui, karena jika salah satu dari kedua syarat tersebut tidak terpenuhi, maka peserta didik tidak bisa untuk mengikuti pembelajaran sehingga akan tertinggal dalam mendapatkan dan memahami suatu materi pembelajaran.

Proses pembelajaran yang seperti ini, dirasa sangat kurang efektif. Salah satunya yang sering terjadi adalah kurang maksimalnya pemahaman yang didapatkan oleh peserta didik. Kurangnya pemahaman peserta didik ini dipengaruhi oleh berbagai faktor. Misalnya saja meskipun peserta didik memiliki sarana yang cukup (paket data), akan tetapi tidak menutup kemungkinan apabila signal internetnya lemah. Lemahnya signal bisa saja dipengaruhi oleh kondisi geografis suatu wilayah (hasil observasi). Signal yang lemah ini berdampak pada kurang maksimalnya peserta didik dalam mendengarkan penjelasan materi pembelajaran. Pendengaran yang terputus-putus atau pendengaran yang tidak menyeluruh terhadap materi akan sangat berdampak terhadap lemahnya pemahaman peserta didik secara utuh. Peserta didik akan sulit memahami materi secara menyeluruh sehingga tidak menutup kemungkinan akan menimbulkan pemahaman baru yang kurang sesuai dan kebenarannya kurang kredibel.

Proses pembelajaran daring ini secara tidak langsung akan berdampak pada penurunan kompetensi peserta didik dalam aspek kognitif jika tidak dilakukan dengan perencanaan yang sempurna. Aspek kognitif berhubungan dengan kemampuan daya Jurnal Riset Madrasah Ibtidaiyah (JURMIA). Vol. 2, No. 1 
pikir anak (thinking), memecahkan suatu permasalahan (problem solving), menentukan dan mengambil keputusan (decision making), kecerdasan (intelegence), dan juga bakat (aptittude) (Dariyo, 2007:43). Aspek kognitif memiliki tujuan berorientasi pada kemampuan daya berfikir yang meliputi intelektual yang sederhana seperti remember sampai dengan kemampuan dalam menyelesaikan atau memecahkan suatu permasalahan yang menuntut peserta didik untuk mampu mengkorelasikan dan juga menggabungkan berbagai gagasan, ide, metode, ataupun prosedur yang dipekajarinya sebagai panduan untuk memecahkan suatu permasalahan (kahfi, 2021).

Segala kegiatan yang mencakup kegiatan mental (otak) termasuk dalam ranah kognitif. Bloom berpendapat bahwa jenis upaya apapun juga berhubungan dengan aktivitas otak, maka termasuk dalam ranah kognitif. Terdapat banyak kegiatan yang tergolong dalam ranah kognitif seperti kemampuan dalam menghafal, memahami, mengaplikasi, menganalisis, mensintesis, serta kemampuan dalam mengevaluasi.

Apalagi dalam lingkup sekolah dasar. Secara psikologi anak dalam usia ini akan lebih mudah memahami suatu konsep materi pembelajaran dengan menggunakan media atrau dengan melihat dan mengalami fenomena-fenomena yang konkrit (maharani, 2017). Pada tahap ini anak akan mulai mampu melakukan penalaran secara logis terhadap hal-hal yang sifatnya konkret, sedangkan untuk hal-hal yang bersifat abstrak masih sulit dan belum mampu (chusna \& utami, 2020). Sehingga dengan adanya media konkrit tersebut akan menjadi pengalaman belajar bagi peserta didik dan akan menguatkan retensi yang dimilikinya. Dengan adanya retensi yang kuat, peserta didik akan mengalami peningkatan dalam kompetensi kognitifnya.

Untuk meningkatkan aspek kognitif peserta didik terdapat banyak metode yang bisa diterapkan. Menurut Piaget (Santrock, 2007: 260-261) dalam proses pembelajaran bisa menerapkan pembelajarean dengan menggunakan pendekatan kontruktivis, memfasilitasi peserta didik dalam belajar, mempertimbangkan pengetahuan dan juga tingkat pemikiran peserta didik, menggunakan penilaian terus menerus, meningkatkan kemampuan intelektual anak, dan menjadikan lingkungan kelas menjadi ruang eksplorasi, media, dan juga penemuan. Semua metode tersebut akan maksimal jika dalam pelaksanaannya dilakukan secara tatap muka. Karena pembelajaran secara tatap muka akan memudahkan peserta didik dan juga pendidik untuk saling berkomunikasi dan memberikan feedback terhadap apa yang dipelajarinya (hasil observasi).

Dalam sekolah tingkat dasar di Madrasah Ibtidaiyah, proses pembelajaran secara daring belum bisa menerapkan metode-metode yang mendukung peningkatan aspek kognitif peserta didik. Metode yang sering diterapkan dalam proses pembelajaran adalah dengan memberikan materi melalui video yang diambil dari youtube, memberikan sedikit penjelasan dalam bentuk video, memberikan bacaan, dan yang paling sering adalah dengan memberikan tugas.

Proses pembelajaran yang seperti ini akan merugikan peserta didik dikarenakan pemahaman yang didapatkan tidak maksimal jika tidak ada pendampingan atau support dari orang tua. Orang tua memiliki peran yang sangat penting selama proses pembelajaran daring (chusna \& utami, 2020). Hal ini dikarenakan anak akan lebih banyak menghabiskan waktu di rumah bersama dengan orang tua. Padahal pada realitanya, tidak semua orang tua memiliki kemampuan untuk mendampingi anaknya dalam belajar. Salah satu alasannya adalah karena minimnya pengetahuan orang tua atau wawasan orang tua terhadap materi pembelajaran. Selain itu tidak semua orang tua juga melek akan kecanggihan teknologi. Sehingga tidak sedikit orang tua yang lepas tangan ketika anaknya sedang belajar dengan sistem daring. 
Selain berdampak pada rendahnya aspek kognitif anak, pembelajaran daring juga menimbulkan rasa bosan pada peserta didik, karena dalam proses pembelajarannya kurang kreatif dan juga kurang inovatif. Sehingga peserta didik lamakelamaan akan merasa malas untuk belajar yang akhirnya akan sangat berpengaruh terhadap peningkatan aspek kognitif peserta didik. Dampak lain dari pembelajaran daring adalah ditemukannya siswa yang mengalami penurunan motivasi belajarnya selama pembelajaran daring dibandingkan dengan motivasi belajar saat tatap muka yang disebabkan siswa banyak mendapat bantuan menyeluruh dan langsung dari orang tua, saudara atau tetangga yang mendampingi siswa saat melakukan pembelajaran daring. dampak pendampingan daring seperti itu akan berakibat negatif terhadap perkembangan siswa kedepannya. Dampak negatif terhadap perkembangan siswa yaitu siswa lebih tidak peduli atau terkesan meremehkan terhadap setiap tugasnya. Selain itu, siswa juga akan lebih banyak menggantungkan diri terhadap bantuan orang lain sehingga menjadikan dirinya pribadi yang kurang mandiri. Pada akhirnya kondisi siswa yang kurang mandiri tersebut juga akan sering membuat wali murid kesulitan saat mengarahkan siswa untuk menyelesaikan setiap tugas dan tanggungjawab di sekolahnya (Suttrisno, 2021).

Oleh karena itu, untuk meminimalisir dampak negatif yang ditimbulkan oleh pembelajaran daring terhadap kemampuan aspek kognitif peserta didik, seorang pendidik haruslah memiliki berbagai keterampilan dalam menyiapkan pembelajaran yang kreatif dan juga inovatif (hidayati \& aslam, 2021). Karena pendidik merupakan salah satu unsur terpenting serta seseorang yang memiliki peran penting dalam proses pendidikan (aziz, 2017). Tenaga pendidik dituntut untuk mampu memiliki daya pikir yang kreatif dalam mempersiapkan pembelajaran serta dalam pelaksanannya seperti dalam memanfaatkan media High Technology seperti Zoom Meeting, Google Meet, Whatsapp, Google form, Google classroom, Ms team, dan lain sebagainya (pratama, 2021) Pembelajaran yang kreatif, efektif, dan inovatif ini harus dapat diaplikasikan selama pembelajaran daring berlangsung. Karena seorang pendidik memiliki tanggung jawab yang besar untuk mengembangkan aspek afektif (rasa), kognitif (cipta), dan psikomotor (karsa) peserta didik (ramli, 2015). Melalui pembelajaran yang kreatif dan efektif, dan inovatif diharapkan peserta didik tetap mampu mengembangkan berbagai keterampilan dan kemampuan yang dimiliki dalam bidang afektif, kognitif, dan psikomotorik sehingga tujuan pembelajaran tetap bisa tercapai.

\section{KESIMPULAN DAN SARAN}

Covid-19 yang muncul secara tiba-tiba telah mampu memporak-porandakan berbagai aspek seperti aspek ekonomi, aspek budaya, dan juga dalam aspek pendidikan. Dalam aspek pendidikan juga terdapat peraturan baru yang harus diterapkan. Peraturan tersebut terkait dengan adanya peubahan dalam proses pembelajaran yang awalnya dilakukan secara tatap muka kini harus dilakukan dengan cara daring (dalam jaringan). Proses pembelajaran daring ini memerlukan kesiapan yang matang terkait penggunaan strategi, media, pemanfaatan teknologi untuk mendapatkan proses pembelajaran yang maksimal dan mampu meningkatkan kemampuan kognitif anak.

Akan tetapi pada kenyataannya, tidak semua sekolah mampu menerapkan sistem belajar daring dengan sempurna. Terlebih lagi sekolah-sekolah yang ada di daerah pelosok atau daerah pegunungan mengalami kesulitan dalam pemerolehan signal yang menyebabkan proses pembelajaran kurang maksimal. Selain itu, proses pembelajaran yang monoton dengan hanya mengirimkan video serta pemberian tugas terus menerus membuat peserta didik kurang maksimal dalam memahami materi yang dipelajari. Selain faktor sekolah, pendampingan orang tua juga sangat diperlukan, karena peserta didik akan lebih banyak menghabiskan waktunya dirumah dari pada di 
sekolah, sehingga perlu adanya pengawasan dan bimbingan yang ketat agar anak bisa meningkatkan kemampuan kognitifnya. Akan tetapi pada kenyataannya tidak semua orang tua memiliki waktu dan juga pengetahuan yang cukup untuk mendampingi anak belajar dirumah. Akibat dari berbagai kendala tersebut, berdampak pada rendahnya kemampuan kognitif peserta didik.

\section{REFERENSI}

Amreta , M. Y., Fitria, D. N., \& Syadiah, H. (2021). pemngehasuyhushbns dshduhd duhedu. Cendikia (Jurnal Pendidikan Islam), 342-343.

Arsyad, A. (2011). Media pembelajaran. Jakarta: penerbit rajawali press.

Aziz, a. (2017). Komunikasi pendidik dan peserta didik dalam pendidikan islam. Mediakita, 1(2), 174.

Chusna, p. A., \& utami, a. D. (2020). Dampak pandemi covid-19 terhadap peran orang tua dan guru dalam meningkatkan kualitas pembelajaran daring anak usia sekolah dasar. Premiere, 2(1), 12.

Dariyono, a. (2007). Psikologi perkembangan anak tiga tahun pertama. Bandung: refika adhitama.

Dewi, W. A. (2020, April). Dampak covid-19 terhadap implementasi pembelajaran daring di sekolah dasar. Edukatif: Jurnal Ilmu Pendidikan, 2, 56.

Haryadi, t., \& aripin. (2015). melatih kecerdasan kognitif afektif, dan psikomotorik anak sekolah dasar melalui perancangan game simulasi "warungku". andharupa jurnal desain komunikasi visual \& multimedia, 1(2), 41.

Hidayati, i. d., \& aslam. (2021). efektivitas media pembelajaran aplikasi quizizz secara daring terhadap perkembangan kognitif siswa. jurnal pedagogi dan pembelajaran, $4(2), 251$.

Kahfi, a. (2021). dampak pembelajaran daring di masa pandemi covid-19 terhadap perkembangan kognitif anak. dirasah, 4(1), 19.

Kuntarto, E. (2017). Kefektifan model pembelajaran daring dalam perkuliahan bahasa indonesia di perguruan tinggi. journal indonesia language education and literature, 3(1), 99-110.

Kusuma, W. S., \& Sutapa, P. (2021). dampak pembelajaran daring terhadap perilaku sosial emosi anak. jurnal obsesi: jurnal pendidikan anak usia dini, 5, 1636.

maharani, b. y. (2017, juli). penerapan model pembelajaran discovery learning berbantuan benda konkret untuk meningkatkan hasil belajar ipa. e-journal mitra pendidikan, 1(5), 552.

N, S. A. (2019). pengaruh daring learning terhadap hasil belajar ipa siswa sekolah dasar. (p. 1). prosiding seminar nasional sains dan entrepeneurship. 
Nata, a. (2009). perspektif islam tentang strategi pembelajaran. jakarta: kencana preanada media group.

Pratama, a. p. (2021). pengaruh pembelajaran daring terhadap motivasi belajar siswa sd. mahaguru jurnal pendidikan guru sekolah dasar, 2(1), 90.

Ramli, m. (2015). hakikat pendidikan dan peserta didik. jurnal tarbiyah islamiyah, 5(1), 63.

Suttrisno. (2021). Analisis Dampak Pembelajaran Daring terhadap Motivasi Belajar Siswa Madrasah Ibtidaiyah. Jurnal Riset Madrasah Ibtidaiyah (JURMIA), 1(1), 110. https://doi.org/10.32665/jurmia.v1i1.190 